\title{
Wojciech Kaczmarek
}

\section{Dramat imaginacyjny Wyspiańskiego \\ O niedrukowanej pracy Ireny Sławińskiej}

Z materiałów, jakie zawiera przechowywane w Katedrze Dramatu i Teatru KUL archiwum profesor Ireny Sławińskiej (1913-2004), pozostała w rękopisie praca, przygotowana jako rozdział do książki lub większy artykuł, zatytułowana Dramat imaginacyjny Stanisława Wyspiańskiego'. Rękopis, zapisany atramentem na osiemdziesięciu czterech numerowanych luźnych kartkach w formacie A5, przypomina podobnie zredagowany manuskrypt książki o tragedii w epoce Młodej Polski. Wydaje się, że obie prace pochodzą z tego samego okresu. Sposób prowadzenia refleksji jest w nich podobny, mocno nastawiony na uchwycenie strukturalnych

\footnotetext{
1 Tekst Sławińskiej ukaże się w ramach serii prac wydawanych przez Katedrę Dramatu i Teatru kUL. Wersja przepisana licząca 38 stron zapisu komputerowego, jest podstawą cytowania w tym artykule.
} 
wyznaczników badanych dramatów i zawartych w nich koncepcji scenicznych. Żadna cytowana pozycja bibliograficzna nie przekracza stanu badań po 1938 roku. Rękopis zawiera poprawki i skreślenia, ale jest ich niewiele, jakby autorka przygotowała ten tekst jako czystopis przeznaczony do przepisania na maszynie. $\mathrm{Na}$ stronie pierwszej, nienumerowanej, widnieje tytuł pracy oraz spis treści:

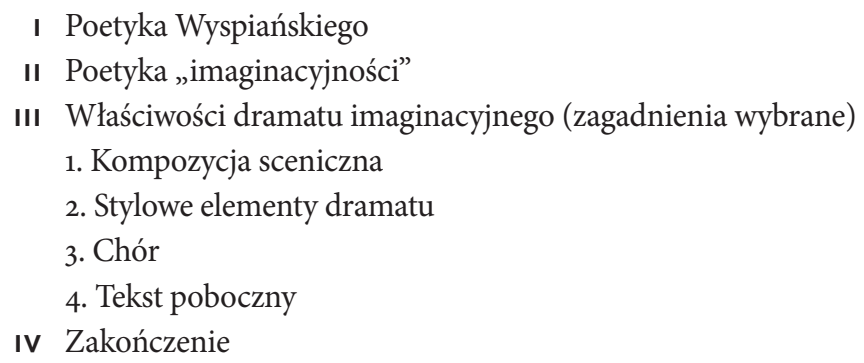

Zastanawiające jest pytanie o związek tej pracy z książką o tragedii w Młodej Polsce $^{2}$. Czy Sławińska chciała włączyć ją do monografii jako wyodrębniony rozdział? $\mathrm{Na}$ pierwszej stronie rękopisu, ponad tytułem i spisem treści, w górnej części kartki widnieje rzymska cyfra viI, zapisana czerwoną kredką, jakby inną ręką. Czy można traktować to jako sygnał, że autorka chciała uczynić z tekstu siódmy rozdział większej całości? Może miała taki plan, lecz naruszyłoby to koncepcję książki skupionej tylko na tragediach z epoki Młodej Polski, w której o tragediach Wyspiańskiego traktował trzeci rozdział. A może tekst powstał wtedy, gdy kształt doktorskiej monografii nie był jeszcze ustalony? Może zamierzała powrócić do zagadnienia przy okazji całościowego opracowania poetyki dramaturgicznej Wyspiańskiego? Odpowiedzi na te pytania nie znamy, a tekst ostatecznie pozostał w rękopisie.

\section{Geneza tekstu}

Prawdopodobnie praca na temat dramatu imaginacyjnego powstała równolegle do przygotowywanej przez Sławińską rozprawy doktorskiej. Postawa badawcza doktorantki bazowała na koncepcji, jaką w Uniwersytecie Stefana Batorego w Wilnie rozwijał wówczas Manfred Kridl, wybitny historyk i teoretyk literatury (1882-1957). Propozycję badań skupionych na strukturalnych zależnościach elementów stanowiących o artystycznym kształcie dzieła literackiego przedstawił w 1936 roku w książce Wstęp do badań nad dziełem literackim. Podjęte tam zagadnienia Sławińska znała z wykładów i seminariów prowadzonych przez

\footnotetext{
${ }^{2}$ Irena Sławińska, Tragedia w epoce Młodej Polski: Z zagadnień struktury dramatu (Toruń: Towarzystwo Naukowe, 1948).
} 
profesora. Koncepcja Kridla wywołała ostrą dyskusję we wszystkich ośrodkach polonistycznych w kraju, przede wszystkim ze względu na rzekomy formalizm i oderwanie badań od kontekstu historycznego. Sławińska nie ukończyła swoich badań przed nadejściem wojny. Obrona jej doktoratu odbyła się na Uniwersytecie Mikołaja Kopernika w Toruniu 20 października 1946. Rozprawę zaś wydano drukiem dwa lata później pod tytułem Tragedia w epoce Młodej Polski: Z zagadnień struktury dramatu.

Niedrukowany tekst o dramacie imaginacyjnym Wyspiańskiego koresponduje zwłaszcza z rozdziałem trzecim tej rozprawy, Tragedia klasyczna Wyspiańskiego. W analizie Meleagra, Protesilasa i Laodamii, Klątwy oraz Sędziów widać ukształtowany przez Kridla sposób myślenia o tekstach - skupienie na poetyce i związkach poszczególnych elementów budujących integralność dzieła. Wyjątkowość dociekań Sławińskiej polegała również na zastosowaniu ciekawej strategii hermeneutycznej. Autorka postanowiła bowiem wyjść od ustaleń samego Wyspiańskiego i na tej podstawie zrekonstruować uobecnioną w jego dramatach koncepcję tragizmu. Z licznych artykułów i książek, do jakich się odniosła, na pewno kluczowa była rozprawa Tadeusza Sinki, Antyk Wyspiańskiego ${ }^{3}$, a także monografie Stanisława Kolbuszewskiego ${ }^{4}$ i Wilhelma Barbasza ${ }^{5}$ lokujące autora Wesela w kontekście historii literatury romantycznej. W zakresie realizacji dramatów Wyspiańskiego na scenie i wpływu tych inscenizacji na badania ściśle literackie i analityczne cenna zapewne była książka Wiktora Brumera ${ }^{6}$. Jednak w sposobie prowadzenia analiz i merytorycznych uściśleń badawczych Sławińska musiała odnieść się przede wszystkim do pracy Stefana Kołaczkowskiego ${ }^{7}$. Kołaczkowski przystąpił do analiz dramatów Wyspiańskiego, przyjmując gotową teorię tragizmu, i uznał, że poeta nie trzymał się jasnych reguł klasycznej tragedii. Sławińska natomiast uważała, że u Wyspiańskiego mamy do czynienia z ewolucyjnym procesem kształtowania się rozmaitych form tragedii:

Zwróćmy się do obszernego studium St. Kołaczkowskiego, poświęconego właśnie zagadnieniom tragizmu. Autor przystępuje do twórczości Wyspiańskiego z wypracowaną już koncepcją tragizmu; za tragizm uważa przecięcie dwóch konieczności i nierozerwalny związek zła i dobra. Analizując dramaty Wyspiańskiego, przekonał się Kołaczkowski, że często akcenty tragiczne leżą poza obrębem tragedii ${ }^{8}$.

\footnotetext{
3 Tadeusz Sinko, Antyk Wyspiańskiego (Warszawa: Instytut Wydawniczy „Bibljoteka Polska”, 1922).

4 Stanisław Kolbuszewski, Stanisław Wyspiański a romantyzm polski (Poznań: Fiszer i Majewski, 1928).

5 Wilhelm Barbasz, Wyspiański na tle romantyzmu (Lwów: Przegląd Humanistyczny, 1932).

6 Wiktor Brumer, Teatr Wyspiańskiego (Warszawa: F. Hoesick, 1933).

7 Stefan Kołaczkowski, Stanisław Wyspiański: Rzecz o tragediach i tragizmie (Poznań: Fiszer i Majewski, 1922).

8 Sławińska, Tragedia w epoce Młodej Polski, 77.
} 
Metoda zastosowana przez Kołaczkowskiego wydawała się Sławińskiej zupełnie nieprzydatna. Swój namysł rozpoczęła od analizy pojęcia tragedii wyłaniającego się wprost ze studium Wyspiańskiego o Hamlecie. Poeta, akcentując „dramat inteligencji”, wskazał, że źródeł tragedii należy szukać w procesach myślowych bohaterów. Analiza procesu myślowego ewokującego tragiczne następstwa zdarzeń stała się więc dla Sławińskiej podstawą próby rekonstrukcji zasadniczych założeń artystycznych tragedii Wyspiańskiego. W pierwszej kolejności prześledziła sposób wprowadzenia podwójnej motywacji zdarzeń:

Wszystkie cztery tragedie posiadają podwójną motywację tego, co określamy zazwyczaj konwencjonalnym terminem „katastrofa”. Jest ona wszędzie wypadkową dwóch sił: transcendentnego losu, działającego niezależnie od człowieka, i moralnej postawy człowieka, ukształtowanej przez jakiś proces duchowy, który ma miejsce w samym utworze. Siły te działają zazwyczaj zgodnie w tym sensie, że bohater „dorasta do losu” i zgadza się na niego 9 .

Podwójna motywacja zdarzeń w każdym dramacie przybiera inny kształt. Dlatego trzeba było prześledzić modyfikacje, jakim dramatopisarz poddał zasadę trzech jedności: czasu, miejsca i akcji. Analizy pokazały, że Wyspiański podchodził do tradycyjnych elementów tragedii klasycznej w sposób bardzo indywidualny, raz dla wzmocnienia „dramatyczności” zdarzeń, innym razem dla ich „zagęszczenia”. Tylko zasada jedności czasu była w tragediach Wyspiańskiego przestrzegana dość rygorystycznie. We wszystkich czas ulega znacznemu zagęszczeniu (wszystkie tragedie - prócz Klątwy - „nocy mają piętno”), nawet kosztem prawdopodobieństwa zdarzeń. Ciekawym zabiegiem artystycznym stała się także próba „pokonywania czasu”: wydłużania jego trwania poprzez pauzy („,koncert wieczorny” w Meleagrze) albo wprowadzanie dygresji i opowiadań (jak w Sędziach) czy też wizji i snów (w Protesilasie i Laodamii). Na percepcję czasu wpływ miały także partie chóralne oraz zróżnicowane tempo dialogów i monologów.

Sławińska poddała obserwacjom również cztery pierwiastki kształtujące, jej zdaniem, formę artystyczną tej grupy dramatów: refleksyjność, dialektykę ${ }^{10}$, epickość i liryzm. Refleksyjność wiązał Wyspiański z „dramatem inteligencji”",

9 Sławińska, 77.

10 Mówiąc o dialektyce, Sławińska ma na uwadze jedną ze sztuk wyzwolonych - artes liberales - sztukę dyskutowania i docierania do prawdy poprzez ujawnianie sprzeczności w sądach przeciwnika.

${ }^{11}$ Ewa Miodońska-Brookes zauważyła, że "dramat inteligencji" Wyspiańskiego był wynikiem przesunięcia akcentu dramatycznego ze sfery estetyki ku egzystencji, a wyobraźnia artystyczna i inteligencja, jako kategorie estetyczne i egzystencjalne, łączyły się u poety z pojęciem „Losu", wyrażającego się w dążeniu do poznania pełni zapisanej w życiu bohatera. Zob. Ewa Miodońska-Brookes, „Imaginacja, fantazja, wyobraźnia, inteligencja (w kręgu myśli Wyspiańskiego)", w: Stanisław Wyspiański: W labiryncie świata, myśli i sztuki, red. Anna Czabanowska-Wróbel (Kraków: Wydawnictwo Uniwersytetu Jagiellońskiego, 2009), 24. 
a więc z płaszczyzną myśli i motywacji bohatera dorastającego do swego „losu”'2. Zrezygnował natomiast $\mathrm{z}$ abstrakcyjnego wymiaru dialektyki (jako walki dwóch idei, stanowisk czy poglądów na życie), a bazował tylko na rozwiązaniach praktycznych (pokazując konkretną sprawę, konflikt, który dotyczy postaci na scenie). Analiza tych składników wykazała dużą oryginalność Wyspiańskiego w budowaniu akcji dramatycznej, całkowicie odróżniającą jego utwory od dramatów innych autorów Młodej Polski.

Książka Sławińskiej o młodopolskiej tragedii, wydana w 1948, nadal stanowi ważne opracowanie zagadnienia. Przyczyniła się nie tylko do zmiany oceny wczesnej twórczości scenicznej Wyspiańskiego, ale też pokazała jego nowatorstwo $\mathrm{w}$ tworzeniu dzieł scenicznych i wpisywaniu w nie koncepcji inscenizacyjnej. Rozpoznania Sławińskiej pozostały w mocy po publikacji monografii Anieli Łempickiej¹3. Sposób myślenia Sławińskiej znalazł natomiast twórczą kontynuację w pracach Ewy Miodońskiej-Brookes pokazujących bogactwo kompozycyjnych środków i form w dziełach dramaturgicznych poety. Wstępne rozpoznania Sławińskiej dotyczące tragedii zostały w pracy uczonej z Krakowa pogłębione o analizy Legionu, Achilleis, Wyzwolenia i Akropolis ${ }^{14}$.

\section{Dramat imaginacyjny}

W kontekście dociekań Sławińskiej nad tragizmem i tragedią młodopolską zrodził się zapewne jej tekst skupiony na wyobraźni teatralnej Wyspiańskiego. Temat był prawie zupełnie nierozpoznany. Mówiło się wprawdzie o wyjątkowej oryginalności świata poetyckiego i malarskości wizji Wyspiańskiego, obserwacje te jednak w niewielkim stopniu dotyczyły kompozycji dramatów. Z dostępnej wówczas literatury przedmiotu mogły zainspirować Sławińską dwie książki: Henryka Balka i Wincentego Jana Ostrowskiego ${ }^{15}$. Obie publikacje ujmowały jednak problem wyobraźni poety raczej od strony psychologicznej i filozoficznej. Ostrowski wskazywał na możliwość przenikania elementów rzeczywistego świata do świata przedstawionego dramatów dzięki ejdetycznej wyobraźni wzrokowej. Pozwalała

12 Najczęściej poeta używał tego terminu w znaczeniu zwykłym, jako codzienne doświadczenie życiowe, ale w wielu momentach los oznacza siłę wyższą, która kieruje życiem bohatera i jest niezmienna w swym finale: „to, co ma być, stać się musi", a równocześnie pozostaje nieprzenikniona. Bohater zmaga się z losem, nie znając wypadków, jakie się zdarzą wjego historii. Zob. Zdenka Marković, Pojęcie dramatu u Wyspiańskiego, tłum. Stanisław Kolbuszewski (Poznań: Księgarnia św. Wojciecha, 1924), 77-99. Sławińska, pisząc swój tekst, znała pracę Marković.

13 Aniela Łempicka, Wyspiański pisarz dramatyczny: Idee i formy (Kraków: Wydawnictwo Literackie, 1973)

14 Zob. Ewa Miodońska-Brookes, Studia o kompozycji dramatów Stanisława Wyspiańskiego (Wrocław: Zakład Narodowy im. Ossolińskich, 1972); Ewa Miodońska-Brookes, Wawel - „Akropolis": Studium o dramacie Stanisława Wyspiańskiego (Kraków: Wydawnictwo Literackie, 1980).

15 Zob.: Henryk Balk, Z badań nad wyobraźniq̨ artystyczną Stanisława Wyspiańskiego (Lwów: Zakład Narodowy im. Ossolińskich, 1927); Wincenty Jan Ostrowski, Wyobraźnia ejdetyczna Stanisława Wyspiańskiego (Poznań: Poznańskie Towarzystwo Filozoficzne, 1934). 
ona, zdaniem badacza, powoływać do życia postaci obdarzone szczególnym sposobem istnienia:

artysta ma dwa światy: świat zewnętrzny, obiektywny, który dzieli z wszystkimi innymi ludźmi, świat spostrzeżeń; drugi - świat swej wyobraźni ejdetycznej, swój własny, którego jest twórcą i obserwatorem, niedostępny bezpośrednio dla innych ludzi. Oba światy są jednak dla poety równie realne, równie żyjące, równie zmysłowe. Świat imaginacji ejdetycznej odbywa się w tej samej przestrzeni fizycznej, w której istnieje świat obiektywny, zewnętrzny. Świat imaginacji ejdetycznej miesza się i stapia się z światem spostrzeżeń, a pomieszanie tych dwu światów, drażniących zmysły, jest pełne uroku i powabu. Stosunek tych dwu światów nigdy nie był jeszcze uwidoczniony w poezji polskiej ${ }^{16}$.

Ten sposób powstawania obrazów mógł być tropem w badaniach, jakie podjęła młoda uczona, chociaż nie potrafimy dziś udowodnić, że właśnie wspomniane książki stały się ich pretekstem. Sławińska jednak widziała tę sprawę inaczej niż Ostrowski, ponieważ cech wyobraźni artystycznej Wyspiańskiego szukała $\mathrm{w}$ oryginalnych rozwiązaniach teatralnych zastosowanych przez poetę. Geniusz autora Wyzwolenia polegał, jej zdaniem, na łączeniu w obrazie scenicznym przeciwieństw, które na pierwszy rzut oka były nie do pogodzenia. Podzielała przekonanie Tadeusza Makowieckiego ${ }^{17}$, że Wyspiański myślał obrazami. W ujęciu Makowieckiego brakowało jednak analizy sposobów łączenia obrazu z tekstem, dźwiękiem, gestem i przestrzenią.

Chociaż użyty przez Sławińską termin „imaginacja” nie został w pracy jednoznacznie zdefiniowany, zatrzymajmy się chwilę nad jego „zawartością”. Autorka przytacza go za Wyspiańskim, dla którego imaginacja znaczyła coś innego niż tylko wizyjność czy wyobraźnia ${ }^{18}$. Aby dojść do tego, jak Wyspiański tworzył imaginacyjne obrazy, Sławińska skupiła się na pokazaniu artystycznych rezultatów przyjętej poetyki:

„Dramatem imaginacyjnym” można by nazwać niemal całą twórczość dramatyczną poety, wyjąwszy może tragedie klasyczne (zresztą w Protesilasie i Laodamii także występują wizje). Jako materiałem dowodowym posłużę się jednak tylko kilkoma utworami, które koncepcję tego dramatu realizują najpełniej (Wesele, Akropolis, Legion, Noc listopadowa, Warszawianka). W pozostałych wizyjność gra rolę podrzędniejszą,

16 Ostrowski, Wyobraźnia ejdetyczna, 43, https://rcin.org.pl/dlibra/doccontent?id=3404z

17 Tadeusz Makowiecki, Poeta - Malarz: Studium o Stanisławie Wyspiańskim (Warszawa: Towarzystwo Literackie im. Adama Mickiewicza, 1935).

18 Wyspiański zazwyczaj używał tego wyrażenia w znaczeniu potocznym, jako wyobraźnia, fantazja, ale w aspekcie swoistej poetyki termin ten ma ściślejsze konotacje, związane z obrazowaniem w malarstwie i plastyce ukazującym kształt imaginacji. Zob. Miodońska-Brookes, „Imaginacja, fantazja, wyobraźnia, inteligencja”, 15-24. 
epizodyczną; wspominam o niej pobieżnie. Kwestia podziałów w obrębie utworów dramatycznych Wyspiańskiego wydaje mi się tak niezwykle skomplikowana właśnie wskutek skrzyżowania różnych pierwiastków, motywów i pokładów. Nawet przy odrzuceniu kryteriów tematycznych (teraźniejszość i przyszłość Polski, motywy historyczne) trudno przeprowadzić klasyfikację opartą na kryteriach kompozycji dramatycznej. Bardzo charakterystycznych trudności dostarcza np. Wyzwolenie, które z jednej strony zawiera ogromny wkład dialektyki, z drugiej zaś realizuje także ów „dramat imaginacyjny” Wyspiańskiego. Każda więc klasyfikacja może być zakwestionowana jako sztuczna i niesłuszna ${ }^{19}$.

Przy doborze sztuk zakwalifikowanych do tej grupy korzystała ze wskazówek samego Wyspiańskiego. Można zasadnie przypuszczać, że pomysł materializowania na scenie imaginacji zrodził się u poety pod wpływem lektury Hanusi Hauptmana, a więc około 1895. Sławińska lokowała genezę tego pomysłu w tym okresie, odwołując się do listu poety do Lucjana Rydla. Według Wyspiańskiego, dzięki imaginacji można zbudować obraz jakby wydobyty z wnętrza człowieka, przekraczający horyzont rzeczywistości „ziemskiej”. Wyspiański pisał do Rydla:

Co zaś do Haneli [Hanusi], której o zgrozo że nie znałem do przedwczoraj, to może sobie przypominasz rozmowę naszą jedną roku zeszłego, gdzie ci mówiłem jako byłoby rzeczą nową i niezmiernie pociągającą przedstawić „imaginacje” osób wprowadzonych jako „główne figury” i wykazać stosunek tych imaginacji do rzeczywistości? [...] głównie chodzi o to, aby zająć się jedną lub dwiema osobami i tej cały świat przedstawić ${ }^{20}$.

Wątek imaginacji u Wyspiańskiego związany był zatem z myśleniem poetyckim, a nie tylko z wyobraźnią malarską i przestrzenną, jak się wydawało wielu krytykom i badaczom. Sławińska z cytowanego fragmentu listu wyciągnęła również wnioski głębsze, dotyczące typu wyobraźni teatralnej Wyspiańskiego:

Tu już rysuje się więc dwoistość postaci: „figury główne” oraz „imaginacje” (później „osoby” i „osoby dramatu” w Weselu), które mają „cały świat” myślowy odtworzyć. Łatwo tu nawiązać do studium o Hamlecie i „dramatu inteligencji” jako istoty wszelkiego dramatu. Imaginacje mają przecież ilustrować świat wewnętrznych przeżyć postaci, przeżyć - jak się przekonamy - przede wszystkim intelektualnych. Wprowadzenie

19 Irena Sławińska, Dramat imaginacyjny Stanisława Wyspiańskiego [rękopis przechowywany w Katedrze Dramatu i Teatru KUL; komputerowy zapis w posiadaniu autora artykułu], 1-2. Następne cytaty z tego źródła lokalizowane są w tekście głównym w nawiasach.

20 List Wyspiańskiego do Lucjana Rydla, 6 marca 1895, w: Stanisław Wyspiański, Listy zebrane, oprac. Leon Płoszewski et al., t. 2, cz. 1, Listy Stanisława Wyspiańskiego do Lucjana Rydla (Kraków: Wydawnictwo Literackie, 1979), 270. Sławińska korzystała z wersji drukowanej w Listach z Teatru, nr 2 (1924). Słowa „imaginacja"Wyspiański używa w różnych zakresach znaczeniowych, raz do określenia statusu osób, sposobu ich istnienia i cech bohatera, a innym razem do wyrażenia właściwości artystycznych stworzonych na scenie zdarzeń. 
imaginacji na scenę dowodzi z jednej strony stałego $\mathrm{u}$ autora zainteresowania wewnętrznym światem człowieka, dramatem jego inteligencji, z drugiej zaś potrzeby dramatyzowania i obrazowania, słowem - instynktu teatralnego (3-4).

Wnikliwa analiza wszystkich elementów składających się na tak rozumianą wyobraźnię imaginacyjną pozwoliła Sławińskiej ustalić główne punkty rozwoju poetyki poszczególnych utworów Wyspiańskiego.

Pierwszym ogniwem teatru imaginacyjnego była tragedia Protesilas $i$ Laodamia. Zjawy i imaginacje są w niej projekcjami stanów psychicznych tytułowej bohaterki, ale Wyspiański powołuje je bardziej w funkcji scenicznej „ozdoby” niż jako osoby dramatu, inaczej niż później w Weselu czy Nocy listopadowej. Różnica polega przede wszystkim na roli, jaką tego rodzaju figury mają do spełnienia w utworze: $\mathrm{z}$ wizji stają się czynnikiem aktywnym w procesie zdarzeń scenicznych. Sławińska zauważyła, że już w Legionie autor świadomie zaciera różnicę między postaciami realnymi a widmami. Charakterystyczna pod tym względem jest scena dziesiąta, w której imaginacje Krasińskiego i Mickiewicza przybierają formę obrazów scenicznych:

W zestawieniu z Protesilasem i Laodamią, Legion rozszerza więc znaczenie imaginacyjności dramatu, pokazuje, jak ze słów żywych postaci wysnuwa się z wolna obraz - jak słowo obleka się w kształt plastyczny. Przy tym zawsze świat wizyjny ściśle odgranicza się od rzeczywistego. W Legionie też obserwujemy wzrost znaczenia i funkcji, jaką uzyskują imaginacje: one to wpływają na losy bohaterów: Sława wzywa Mickiewicza, wizja św. Andrzeja umacnia go w „szaleństwie krzyża”. Natomiast „świat rusalny” Mickiewicza odgrywa raczej bierną rolę, jest ilustracją do pewnych strun w duszy poety, a poza tym także pięknym pomysłem - malarskim raczej niż scenicznym, bo teatralnie rzecz się wydaje nie do zrealizowania (8).

Kolejnym krokiem w budowaniu poetyki imaginacyjnej było Wesele, w którym poeta dokonał znamiennego rozróżnienia ontologicznego statusu postaci biorących udział w zdarzeniach scenicznych. Podzielił wszystkie dramatis personae na dwie kategorie: „osoby” (postaci realne) i „osoby dramatu” (imaginacje albo widma). Sławińska uwydatniła zasadniczy skutek tego zabiegu: przeniesienie scen wizyjnych na poziom „dramatu inteligencji”. W ten sposób cały proces dramatyczny przeniesiony został do wnętrza bohaterów. Nowością, jaką zastosował tu Wyspiański, było splecenie obu płaszczyzn utworu: realnej i wizyjnej. Tylko z pozoru rozmowy bohaterów przynależą do świata spraw bieżących i politycznych, w gruncie rzeczy wiążą się bezpośrednio $\mathrm{z}$ wydarzeniami, w które zaangażowane są „osoby dramatu”.

Te rozmowy i przeżycia z nimi związane składają się na drugi „dramat” utworu, zrazu zupełnie odrębny, a zespolony z pierwszym, realnym, dzięki Wernyhorze i jego 
rozkazom. W ten sposób przestaje istnieć rozdział dwóch światów: rzeczywistość i zwid splatają się w jedną wizję i w tym wspólnym już świecie rozgrywa się Wesele. Sprawa najważniejsza. Nad wszystkim panuje Wielki Reżyser - Chochoł, „nieustanną muzyką przemożny” (9).

W Weselu zatem Wyspiański nie tylko przeniósł wymiar wizyjny do głównego nurtu zdarzeń, lecz także związał go strukturalnie z planem „realnym”21. Podobną metodę łączenia obu planów zastosował poeta w Wyzwoleniu. Autorka pokazała ten artystyczny zabieg na przykładzie scen z maskami:

Maski - to czyste abstrakcje - myśli, których jedynym zadaniem jest pobudzić myśl Konrada - pomagać w jej rozwoju - znaczyć w jej biegu kolejne stadia. Sądzę, że chodziło tu przede wszystkim Wyspiańskiemu nie o plastyczny kształt dla tych abstrakcji ani o względy dekoracyjno-malarskie (jak w Legionie), ale wyłącznie o dramatyczność (10).

„Strategia imaginacyjna” Wyspiańskiego nie dotyczyła jednak ukazywania samych wytworów myśli głównego bohatera. Konrad musiał przecież skonfrontować się także z Eryniami, które miały żywot autonomiczny, a w planie zdarzeń scenicznych działały niezależnie od realizowanego przez niego scenariusza. Wprowadzenie Erynii do świata przedstawionego było więc kolejnym krokiem poszerzającym zakres i formułę poetyki imaginacyjnej Wyspiańskiego.

Najmocniej ta poszerzona skala poetyki imaginacyjnej ujawniła się w Akropolis i w Nocy listopadowej. Wielu badaczy, między innymi Ortwin, Borowy czy Makowiecki, wskazywało na szczególny charakter sposobu działania wyobraźni Wyspiańskiego w tych dramatach. Poeta łączył sceny umieszczone na tle teatralnej scenografii z wizjami odtwarzającymi konkretne miejsca: katedrę wawelską czy Łazienki. Dzięki jego wyobraźni scenicznej funkcje i znaczenie różnych elementów tych miejsc (aleje, schody, drzwi, gobeliny, pomniki) zostały zestrojone ze scenografią, oświetleniem i kostiumami aktorów. Sławińska zaproponowała odczytanie utworów w kluczu rozwijanej przez poetę koncepcji dramatu imaginacyjnego:

Oba utwory, Akropolis i Noc listopadowa, które możemy traktować jako „dramatu imaginacyjnego" stadium końcowe, ostateczne, czynią świat wizyjny istnieniem odrębnym, mającym dla siebie samego swój własny sens. W Nocy listopadowej Pallas i Niki istnieją naprawdę, nie są wytworem wyobraźni podchorążych. Słusznie podkreślają Sinko

\footnotetext{
${ }^{21}$ Nie ma tu miejsca na poszerzenie tej problematyki o praktykę inscenizacyjną, która zapewne była znana Sławińskiej. WWilnie, w okresie gdy działał tam zespół Reduty (1925-1929), Osterwa wystawił Wyzwolenie (1925). Wesele (1926) oraz w jednym spektaklu fragmenty Sędziów i Nocy listopadowej (1927). Inscenizacje odbiegały koncepcyjnie od realizacji warszawskich, Iwowskich i krakowskich. Dzięki rozmowom Osterwy ze Stefanem Srebrnym, a także przy udziale Iwo Galla, zaproponowano nowy sposób grania właśnie scen wizyjnych, zwłaszcza w Weselu i scen z Maskami w Wyzwoleniu. Otrzymały one oryginalny wymiar artystyczny bez nadmiernego korzystania z odniesień do kultury ludowej. Analiza tych realizacji byłaby ciekawym poszerzeniem obserwacji, jakie Sławińska poczyniła w swoim tekście.
} 
i Borowy analogię z Homerem. Podobnie jak w Iliadzie świat bogów kieruje życiem ludzi, tak też w Nocy listopadowej Pallas, Ares dzierżą w swym ręku ster wypadków (11).

W dramacie imaginacyjnym świat wizji i świat realny mogą więc nie tylko istnieć obok siebie, lecz także łączyć się do tego stopnia, że finalnie imaginacje odgrywać będą nawet nadrzędną rolę w zdarzeniach scenicznych ${ }^{\mathbf{2 2}}$. Przenikanie się obu światów na scenie nie unifikuje jednak realności z imaginacją, lecz świadomie podkreśla ich odrębność:

Przenikają się nawzajem te światy, stają obok siebie, jak gdyby na jednej płaszczyźnie. Nie znaczy to jednak, aby miały zatracić swój odrębny charakter. Wyspiański nigdy przecież nie dążył do iluzjonizmu, do teatru realistycznego i dlatego też nigdy nie kazał swoim imaginacjom udawać istot realnych. Przeciwnie, zawsze podkreślał ich „odrębność”. Wprowadzał je jako postaci przynależne do innego świata, ale niemniej konkretne. Konkretność ta wypływa oczywiście przede wszystkim z jego malarskiego i teatralnego instynktu, z konieczności widzenia postaci. Wyspiański - jak mówi T. Makowiecki - unika „nieprawdy fikcji i nieprawdy szablonu”. Stąd ewolucja „imaginacyjnych” elementów dramatu coraz bardziej zaciera ich fikcyjność, a zmierza ku homeryckiemu typowi bóstw, istniejących przecież realnie, choć nie w ludzkim świecie. Na tę ewolucję kładłam zresztą specjalny nacisk (11-12 $)^{\mathbf{2 3}}$.

W poszukiwaniu odpowiedzi na pytanie o szczególną rolę imaginacyjności w dramatach Wyspiańskiego Sławińska zwróciła uwagę na ich kompozycję. Interesował ją przede wszystkim sposób, w jaki poeta potraktował kategorie akcji i miejsca. Obserwacje poczynione w tym obszarze jeszcze raz potwierdzały oryginalność Wyspiańskiego. W budowaniu obrazu scenicznego imaginacyjność zaciera bowiem obie kategorie: sceny stają się niekiedy fragmentaryczne, o rozluźnionej spoistości, poeta wzbogaca je o różne motywy uboczne. Na przykład przestrzeń akcji, z uwagi na znajdujące się w jej obrębie przedmioty (pomniki, gobeliny, rzeźby, obrazy), staje się punktem wyjścia do nowych scen i często do zmiany akcji:

Wyspiański traktuje teren nie tylko jako tło, ale wyznacza mu daleko ważniejszą rolę, wiąże z nim postaci realne, a także - daleko silniej - zjawy; stąd też postaci tworzą z terenem całość nierozerwalną, którą Wyspiański nazywa „sceną dramatyczną”. Jesteśmy bardzo daleko od konwencjonalnych tarasów tragedii klasycznej. Łazienki z posągiem

\footnotetext{
22 Podobne stanowisko dotyczące wyobraźni Wyspiańskiego zajął Zbigniew Raszewski, "Paradoks Wyspiańskiego”, Pamiętnik Teatralny 6, z. 3-4 (1957): 343-46o. Zauważył, że sposób tworzenia przez poetę wizji scenicznej oparty był z jednej strony na zróżnicowaniu poziomu sceny, a z drugiej na jej rozbiciu na wiele planów. Wywodził tę metodę nie tyle z tradycji malarskich, jakie przypisywano Wyspiańskiemu, ile z jego znajomości zasad architektury. Zob. Raszewski, 445.

23 Warto zauważyć, że Raszewski, jeszcze mocniej niż Makowiecki, akcentował potrzebę teatralnej konkretyzacji wizji, bo w teatrze wszystkie postacie, nawet widma, trzeba przedstawić jako konkret.
} 
„Białego Króla”, aleją, Theatrum Króla Jegomości - wszystko dla Wyspiańskiego ma swoje własne życie i własną historię (17).

Szczegółowe obserwacje Sławińskiej pozwoliły dokonać wglądu w strukturę kompozycyjną i stylową dramatów imaginacyjnych. Badaczka zauważyła dwa czynniki określające wizyjność tych sztuk. Pierwszym była specjalna rola poezji lirycznej. Przybierała ona różne formy i pełniła rozmaite funkcje w procesie dramatycznym (dramatyce). Stawała się najpierw składnikiem dialogów, podkreślając w ten sposób nastrojową i dźwiękową wartość wypowiadanych słów oraz wagę ich doboru, a następnie wpływała - poprzez refreniczność, często w powiązaniu z mimiką i gestem - na rytmizację scen. Drugim elementem kompozycyjnym dramatów imaginacyjnych była ich refleksyjność, związana zresztą z „intelektualizmem” wszystkich tekstów scenicznych Wyspiańskiego. „Dramat inteligencji”, czyli wewnętrzne zmaganie się postaci z losem, rozwijał się najmocniej w scenach monologowych, wypowiedziach chórów oraz $\mathrm{w}$ dialogach bohaterów $\mathrm{z}$ postaciami fantastycznymi. Sławińska, sumując te obserwacje, zauważała:

Różnorodnie wyrażona refleksyjność mieści się jednak zawsze w ramach poezji, nigdy nie wykracza poza nie. Natomiast dialektyka, która graniczy z refleksyjnością ze względu na swój intelektualny charakter, często wyraźnie przeradza się w prozaizm. Nie tylko znikanie wiersza w takich partiach składa się na prozaizm: równolegle z zanikiem oprawy dźwiękowej, właściwej wierszowi, usuwa poeta inne czynniki poetyckiego stylu: zdobnictwo, przekładnie, refreny (24).

Osobliwe znaczenie nadał też Wyspiański chórom. Sławińska poświęciła tym innowacjom osobny podrozdział, wskazując na ich szczególne cechy i funkcje. Widziała w chórach nie tylko realizację efektów lirycznych, ale także odwołania do elementów muzycznych, tak przecież go inspirujących zwłaszcza w Danielu i Legionie. Wprowadzanie do tekstu licznych recytatywów, dwugłosów, pieśni, inwokacji stwarzało kompozycyjny zestaw elementów spinających strukturę tych dramatów. Poeta zróżnicował bowiem chóry przede wszystkim po to, by podkreślić ich rolę kompozycyjną w utworze:

Najczęściej chór dialoguje z przodownikiem, innym znów razem służy za tło dźwiękowe dla jakiegoś pierwszoplanowego dialogu (Legion), czy monologu (sc. Ix Nocy listopadowej). Niekiedy spotykamy w ogóle rozmowę dwóch chórów (Achilleis), lub chór zostaje rozbity na cały szereg pojedynczych, anonimowych głosów, które kolejno się wypowiadają. Związek tego typu fragmentów z chórem wydaje mi się niewątpliwy. Po prostu znika tylko „unisono”, a jawi się zorganizowana wg praw kompozycji chóralnej - wielogłosowość. Tak np. do chóru zbliża się scena z falami w Achilleis, gdy kolejno przepływające fale powtarzają jedną dominującą myśl. Powstaje z tych głosów jakby jedna pieśń chóralna. Podobnie rozbity na 4 głosy jest Chorus Eumenid 
w IV akcie Akropolis. Przodownikowi chóru - Nocy - odpowiadają jednogłośnie lub kolejno (29-30).

Chóry miały przede wszystkim wzmacniać poetycki charakter dramatów Wyspiańskiego ${ }^{24}$. We wszystkich dramatach imaginacyjnych możemy obserwować prawdziwą inwazję poezji lirycznej, ale nie ona jest zasadą „poetyckości” tych utworów. Właśnie dzięki operowaniu scenami chóralnymi Wyspiański przeciwstawiał się zastanym konwencjom teatralnym i świadomie tworzył własny teatr, którego celem- jak mówił, powołując się na Shakespeare’a - miało być odsłanianie prawdy o człowieku i jego pragnieniu wieczności.

Szczególną uwagę poświęciła też Sławińska refleksji nad tekstem pobocznym w dramatach imaginacyjnych. Jej zdaniem zyskiwał on w tych utworach nowe znaczenia i funkcje. Poeta poszerzał bowiem zakres uwag inscenizacyjnych: w Protesilasie i Laodamii dotyczyły jeszcze przede wszystkim dekoracji, później - na przykład w Nocy listopadowej i Akropolis - podkreślały mocniej węzłowe punkty kompozycji scenicznej, koncepcję poszczególnych postaci i właściwą interpretację ich działań scenicznych. Tekst didaskaliów w coraz większym stopniu wpływał na całość dramatu, co zauważyli też inni badacze. Zwłaszcza że artysta wprowadzał do tekstu pobocznego elementy poezji, łącząc didaskalia poetyckie z prozą, często rytmizowaną, by stworzyć w ten sposób nastrój, koloryt i kompozycję malarską całej sceny ${ }^{25}$.

Przemiany tekstu pobocznego prześledziła Sławińska dokładniej w trzech dramatach: w Wyzwoleniu, Akropolis i Nocy listopadowej. Techniczna funkcja didaskaliów poszerzona została tam o elementy artystycznego opisu zdarzeń, które uzupełniały dialogi i nie tyle spełniały rolę introdukcji, ile dawały możliwość wprowadzenia nowych motywów lub elementów stanowiących osnowę kolejnych scen dramatu. Funkcjonowały także jako komentarz do zdarzeń scenicznych. Wyraźnie widać to w didaskaliach w Nocy listopadowej i Akropolis:

Wskazówki reżyserskie, opis dekoracji, postaci czy opowiadanie o mających się rozegrać wypadkach, wreszcie czysto znaczeniowy czy też artystyczny komentarz do postaci i zdarzeń - wszystkie te funkcje tekstu pobocznego rozszerzają oczywiście praktyczną

24 Sławińska wyjaśniła znacznie później kategorie odnoszące się do dramatu poetyckiego, zob. Irena Sławińska, „Ku definicji dramatu poetyckiego", w: Sceniczny gest poety: Zbiór studiów o dramacie (Kraków: Wydawnictwo Literackie, 196o), 221-265. Jednak już wówczas, gdy analizowała dramaty imaginacyjne Wyspiańskiego, wskazała na kilka elementów konstytutywnych dla dramatów poetyckich: poetyckość dramatu nie zależy od formalnych wyznaczników stylistycznych, od formy wierszowanej użytej w dialogach, ale od „ładu świata", jaki jest w dramacie przedstawiony, zakresu i odniesień, jakie cechują działania postaci, przede wszystkim w obszarze motywacji, a także od przenikania się świata realnego i nadnaturalnego.

25 Ten wątek podjęło potem wielu badaczy, m.in. Maria Prussak, Wyspiański w labiryncie teatru (Warszawa: Wydawnictwo Instytutu Badań Literackich PAN, 2005). Uwagi Sławińskiej nie sąjuż dzisiaj tak odkrywcze, jak w momencie pisania tekstu. 
rolę tego tekstu, ale jakoś się z nią wiążą i dadzą się sprowadzić do bardzo szeroko pojętej poetyckiej interpretacji dialogów (35).

Przeprowadzone analizy, ukierunkowane zazwyczaj na wydobycie nowatorstwa Wyspiańskiego w obrębie kompozycji scenicznej i zastosowanych form artystycznych, doprowadziły Sławińską do końcowego wniosku o wyjątkowym charakterze nie tylko dramatów imaginacyjnych, ale całej dramaturgii poety na tle Młodej Polski:

Dramat młodopolski, szczególnie utwory objęte tytułem dramatu poetyckiego, operują także postaciami fantastycznymi. Differentia specifica Wyspiańskiego to oblekanie w kształt plastyczny myśli bohaterów, ożywianie posągów i obrazów. W ten sposób myśl bohatera - zawsze najważniejszy czynnik utworu - staje się osią całego dramatu w obu jego przekrojach: „dramatu inteligencji” $i$,żywego obrazu”, jeśli tym terminem oznaczymy malarską koncepcję scen. „Imaginacyjność” dotyczy więc nie tylko pochodzenia postaci, ale w równej mierze wizualności samego dramatu, jego konkretności, plastyki. Zresztą na „oglądowość” dramatu Wyspiańskiego składają się prócz wzrokowych możliwości liczne efekty słuchowe. Tak realizuje się symbioza wrażeń zmysłowych i czystej poezji, bardzo charakterystyczna dla Wyspiańskiego i problemu teatralności, który tutaj zresztą został całkowicie pominięty (37).

Studium Sławińskiej pozostaje też wyraźnym śladem wnikliwości badawczej autorki i koncepcyjnego talentu interpretacyjnego, który już niebawem rozbłyśnie w jej dojrzałych pracach badawczych. Twórczość Wyspiańskiego będzie ważnym punktem odniesienia aż do końca jej aktywności naukowejej.

\section{Konkluzja: istota geniuszu Wyspiańskiego}

Wyraźne przesunięcie momentu ukształtowania wizji nowego teatru na wczesny okres twórczości scenicznej Wyspiańskiego, czyli rok 1895, to chyba najważniejsza konkluzja płynąca z podjętych analiz. Badania Sławińskiej nad wyobraźnią artystyczną Wyspiańskiego, przede wszystkim nad jego poetyką imaginacyjną, pozostawały dotąd refleksją zamkniętą $\mathrm{w}$ archiwum. Być może publikacja zapomnianego tekstu przyczyni się do ożywienia badań nad tym zagadnieniem. Oczywiście istnieje bardzo rozległa i wieloaspektowa literatura przedmiotu, odnosząca się do problematyki poruszanej w rozprawie Sławińskiej. W znakomitych

${ }^{26}$ Zob. „Bibliografia prac Ireny Sławińskiej 1933-2002”, w: Świat jako spektakl: Irenie Sławińskiej na dziewięćdziesiąte urodziny, red. Wojciech Kaczmarek (Lublin: Wydawnictwo Katolickiego Uniwersytetu Lubelskiego, 2003), 307-353. 
pracach Zbigniewa Raszewskiego ${ }^{27}$, Ewy Miodońskiej-Brookes ${ }^{28}$, Marii Prussak ${ }^{29}$ pojawiają się refleksje nad wyobraźnią sceniczną Wyspiańskiego. Miodońska-Brookes badała również wskazywany przez Sławińską charakterystyczny rys tych dramatów, polegający na włączeniu w dramatyczną wizję pewnych elementów antropologii chrześcijańskiej3 ${ }^{30}$. Brakowało jednak monograficznego ujęcia kwestii dramatu imaginacyjnego ${ }^{31}$.

Sławińska powróciła do problematyki związanej z wizyjnością w studium o Sędziach ${ }^{32}$. Głównym przedmiotem analizy był tu sposób kształtowania wizji teatralnej w perspektywie przemiany wewnętrznej postaci tej tragedii. Teatralna wizja Wyspiańskiego nie tylko wyprzedzała zmiany, jakie w Europie wywołała tak zwana Wielka Reforma, ale ukazała je w takiej intensywności, która już nigdy później się nie powtórzyła. Na tę wyjątkowość zwrócił uwagę oglądający jedno z przedstawień Sędziów w Paryżu Jacques Copeau ${ }^{33}$, a potem Paul Claudel, odnosząc się nie tylko do tego dramatu, ale do całej twórczości Wyspiańskiego ${ }^{34}$.

Podkreślanie wagi przemian w zakresie poetyki wizyjnej dokonujących się we wczesnych dramatach Wyspiańskiego dość długo nie było akceptowane w głównym nurcie badań nad dramaturgią poety. Obowiązywała tu inna wykładnia, pomniejszająca wartość tych dramatów. Taki ton miały zwłaszcza wpływowe w latach sześćdziesiątych i siedemdziesiątych prace Anieli Łempickiej. W obszernej przedmowie do Dzieł wszystkich Wyspiańskiego dość kategorycznie uznała ona wczesne utwory dramatyczne poety (Legenda, Protesilas i Laodamia, Meleager, Warszawianka, Lelewel, Klatwa, Sędziowie) za „słabe”, „nieporadne” czy w najlepszym wypadku nierówne, wykazujące „wiele poważnych braków”; podkreślała też, że język „naginany do zadań daleko posuniętej stylizacji [...] wychodzi z tych operacji storturowany i dziwaczny"35.

\footnotetext{
27 Raszewski, „Paradoks Wyspiańskiego".

28 Miodońska-Brookes, Studia o kompozycji.

29 Maria Prussak, Wyspiański w labiryncie teatru.

30 Zob. Ewa Miodońska-Brookes, „Mam ten dar bowiem: patrzę się inaczej”: Szkice o twórczości Stanisława Wyspiańskiego (Kraków: Universitas, 1997).

31 Ujęcie problematyki, jakie proponowała Miłosława Bukowska-Schielmann, „ja w śnie narodu przeklętym, uśpiony": Stanisława Wyspiańskiego dramaty-sny (Gdańsk: Wydawnictwo Uniwersytetu Gdańskiego, 1994), skupia się raczej na opisie zjawiska snu i wizji, a mniej na jego strukturze i koncepcji scenicznej.

32 Irena Sławińska, „O badaniu wizji teatralnej Wyspiańskiego", Pamiętnik Literacki 7, nr 3 (1958), 403-423.

33 Jacques Copeau, "Stanislas Wyspiański et les représentations polonaises”, La Nouvelle Revue Français, no. 56 (1913), 299-303.

34 Paul Claudel, Introduction à une conference sur Wyspiański, peintre et poète, prononcée au Grand-Palais à l'Exposition d'art polonaise, 25 VI 1921, zob. A. Łada-Cybulski, Z mrokujaśniejq̨ce słowo; Walka z szatanem; Rzecz o teatrze Stanisława Wyspiańskiego 1907-1931 (Paryż: nakładem autora, 1931), 85.

35 Aniela Łempicka, przedmowa do: Stanisław Wyspiański, Dzieła zebrane, red. Leon Płoszewski et al., t. 1 (Kraków: Wydawnictwo Literackie, 1964), xxIII. Potem autorka powtórzyła, niestety, te niczym nie uzasadnione sądy w monografii, zob. Łempicka, Wyspiański, zwłaszcza podrozdział, „Twórczość wczesna”, 22-26.
} 
Sławińska odpowiedziała Łempickiej syntetycznym artykułem: Nowy teatr Wyspiańskiego ${ }^{36}, \mathrm{w}$ którym ponownie wyłożyła argumenty potwierdzające nowatorstwo wczesnych dramatów poety w kontekście reformy teatru. Zwróciła uwagę tylko na cztery ważne elementy oryginalności tych utworów: przestrzeń, czas, teatralizację słowa, ciszy i gestu oraz funkcje maski teatralnej. Już w swoich wczesnych dramatach, napisanych przed Weselem, Wyspiański wniósł do polskiego teatru: monumentalizm miejsca teatralnego, śmiałe eksperymenty z czasem, bogactwo środków ekspresji teatralnej, a także świadome wykorzystanie maski teatralnej, która syntetyzowała wszystkie tworzywa tego teatru:

Maska teatru Wyspiańskiego — sakralna, misteryjna, antynaturalistyczna — jest przede wszystkim naprawdę teatralna: przemawia ona językiem wszystkich tworzyw teatru. Dojrzała, zanim Teatr Artystyczny w Moskwie rozpoczął swoją działalność, przed wystąpieniem Craiga i Reinhardta, a zapewne całkowicie niezależnie od Appii i Fuchsa. Przed rokiem 1905 żaden naród nie może się poszczycić tak bogatą, zróżnicowaną i oryginalną twórczością teatralną. Wyspiański bezsprzecznie przewyższa Czechowa, Hauptmanna, Shawa, Maeterlincka, nawet młodego Claudela. Bogactwem teatralnych koncepcji staje chyba nawet wyżej od dwóch — starszych od niego o całe pokolenie - gigantów: Ibsena (ur. 1828) i Strindberga (ur. 1849) ${ }^{37}$.

Dopiero taka szeroka skala odniesień gwarantować może, według Sławińskiej, merytoryczną ocenę dramaturgii Wyspiańskiego i dopiero na tej podstawie można wskazać właściwe dla niej miejsce w dziejach kultury literackiej i teatralnej $\mathrm{xx}$ wieku. Dla uczonej przywiązanej do klasycznego etosu badacza, nastawionej na szukanie w utworze prawdy (a więc zawartej w nim koncepcji świata przedstawionego i działającego w tym świecie bohatera), twórczość Wyspiańskiego była szczególnie ważnym polem badań, które w najdojrzalszym okresie jej działalności naukowej zaowocowały budowaniem antropologii teatru.

\section{Bibliografia}

Balk, Henryk. Z badań nad wyobraźniq artystyczna Stanisława Wyspiańskiego. Lwów: Zakład Narodowy im. Ossolińskich, 1927.

Barbasz, Wilhelm. Wyspiański na tle romantyzmu. Lwów: Przegląd Humanistyczny, 1932. Brumer, Wiktor. Teatr Wyspiańskiego. Warszawa: F. Hoesick, 1933.

Bukowska-Schielmann, Miłosława. „ja w śnie narodu przeklętym, uśpiony”: Stanisława Wyspiańskiego dramaty-sny, Gdańsk: Wydawnictwo Uniwersytetu Gdańskiego, 1994.

${ }^{36}$ Irena Sławińska, „Nowy teatr Wyspiańskiego", Zeszyty Naukowe kUL 13, nr 2 (1970), 27-32.

37 Sławińska, „Nowy teatr Wyspiańskiego", 31. 
Kolbuszewski, Stanisław. Stanisław Wyspiański a romantyzm polski. Poznań: Fiszer i Majewski, 1928.

Kołaczkowski, Stefan. Stanisław Wyspiański: Rzecz o tragediach i tragizmie. Poznań: Fiszer i Majewski, 1922.

Łempicka, Aniela. Wyspiański: Pisarz dramatyczny: Idee i formy. Kraków: Wydawnictwo Literackie, 1973.

Makowiecki, Tadeusz. Poeta - Malarz: Studium o Stanisławie Wyspiańskim. Warszawa: Towarzystwo Literackie im. Adama Mickiewicza, 1935.

Marković, Zdenka. Pojęcie dramatu u Wyspiańskiego. Tłumaczenie Stanisław Kolbuszewski. Poznań: Księgarnia św. Wojciecha, 1924.

Miodońska-Brookes, Ewa. „Imaginacja, fantazja, wyobraźnia, inteligencja (w kręgu myśli Wyspiańskiego)”. W: Stanisław Wyspiański: W labiryncie świata, myśli i sztuki, redakcja Anna Czabanowska-Wróbel, 15-24. Kraków: Wydawnictwo Uniwersytetu Jagiellońskiego, 2009.

Miodońska-Brookes, Ewa. „Mam ten dar bowiem: patrzę inaczej”: Szkice o twórczości Stanisława Wyspiańskiego. Kraków: Universitas, 1997.

Miodońska-Brookes, Ewa. Studia o kompozycji dramatów Stanisława Wyspiańskiego. Wrocław: Zakład Narodowy im. Ossolińskich, 1972.

Miodońska-Brookes, Ewa. Wawel - „Akropolis”: Studium o dramacie Stanisława Wyspiańskiego. Kraków: Wydawnictwo Literackie, 1980.

Ostrowski, Wincenty Jan. Wyobraźnia ejdetyczna Stanisława Wyspiańskiego. Poznań: Poznańskie Towarzystwo Filozoficzne, 1934.

Prussak, Maria. Wyspiański w labiryncie teatru. Warszawa: Wydawnictwo Instytutu Badań Literackich PAN, 2005.

Raszewski, Zbigniew. „Paradoks Wyspiańskiego”. Pamiętnik Teatralny 6, z. 3-4 (1957): $343-460$.

Sinko, Tadeusz. Antyk Wyspiańskiego. Warszawa: Instytut Wydawniczy „Bibljoteka Polska”, 1922.

Sławińska, Irena. „Nowy teatr Wyspiańskiego”. Zeszyty Naukowe KUL 13, nr 2 ( 1970): 27-32. Sławińska, Irena. „O badaniu wizji teatralnej Wyspiańskiego”. Pamiętnik Literacki 7, z. 3 (1958): 403-423.

Sławińska, Irena. Sceniczny gest poety: Zbiór studiów o dramacie. Kraków: Wydawnictwo Literackie, 1960.

Sławińska, Irena. Tragedia w epoce Młodej Polski: Z zagadnień struktury dramatu. Toruń: Towarzystwo Naukowe, 1948.

\section{Abstrakt}

\section{Dramat imaginacyjny Wyspiańskiego: 0 niedrukowanej pracy Ireny Sławińskiej}

Artykuł prezentuje nieopublikowany tekst Ireny Sławińskiej Dramat imaginacyjny Stanisława Wyspiańskiego, pochodzący prawdopodobnie z roku 1938. Przywołane zostały możliwe źródła inspiracji oraz najważniejsze kroki badawcze, jakie wykonała Sławińska, 
rekonstruując imaginacyjną poetykę dramatów Wyspiańskiego (Protesilas i Laodamia, Legion, Wesele, Noc listopadowa, Wyzwolenie, Akropolis, Sędziowie). Jej analiza objęła koncepcję przestrzeni, konstrukcję postaci, dialogi, funkcję chórów i didaskaliów, by pokazać, że cechą konstytutywną poetyki imaginacyjnej Wyspiańskiego jest zasada zacierania granicy między światem wizyjnym i realnym poprzez ich strukturalne powiązanie, przy jednoczesnym podkreślaniu ich zasadniczej odrębności. Sławińska przesunęła też moment ukształtowania się wizji nowego teatru Wyspiańskiego na rok 1895. W artykule zasygnalizowano, które wątki jej niepublikowanego tekstu mogą stanowić dziś inspirację dla dalszych badań nad twórczością Wyspiańskiego.

\section{Słowa kluczowe}

Stanisław Wyspiański, dramat poetycki, wizja teatralna w dramacie, Irena Sławińska

\section{Abstract}

\section{Wyspiański's Drama of Imagination: An Unpublished Work by Irena Sławińska}

This article presents an unpublished text by Irena Sławińska: Dramat imaginacyjny Stanisława Wyspiańskiego [Stanisław Wyspiański’s Drama of Imagination], probably dating from 1938. It discusses Sławińska's possible sources of inspiration and her most important research steps in reconstructing the imaginative poetics of Wyspiański's dramas (Protesilas i Laodamia, Legion, Wesele [The Wedding], Noc listopadowa [November Night], Wyzwolenie [Liberation], Akropolis, Sędziowie [The Judges]). Based on an analysis of Wyspiański's concept of space, character construction, dialogue, and the function of the choruses and stage directions, Sławińska argues that a constitutive feature of his poetics of imagination was the principle of blurring the border between the world of vision and the real world by interlinking them structurally, while at the same time emphasizing their fundamental separateness. Sławińska also reassesses the chronology of the formation of Wyspiański's vision of new theater, proposing that it should be dated from 1895 . The article indicates the elements of the unpublished text that today may serve as an inspiration for further research on Wyspiański's work.

\section{Keywords}

Stanisław Wyspiański, poetic drama, theatrical vision in drama, Irena Sławińska

\section{WOJCIECH KACZMAREK}

prof. dr hab., kierownik Katedry Dramatu i Teatru Wydziału Nauk Humanistycznych Katolickiego Uniwersytetu Lubelskiego. Główne obszary badań: różne przejawy dramatu i teatru religijnego w Polsce i w Europie w XIX i xx wieku. 